\title{
Unravelling the Effect of Seaweed Bio Formulations in Relieving Biotic and Abiotic Stress in Rice
}

\author{
Sahana, N. Banakar", K.T. Rangaswami and M.K. Prasanna Kumar \\ Department of Plant Pathology, College of Agriculture, UAS, GKVK, Bengaluru-560065, \\ Karnataka, India \\ *Corresponding author
}

\section{A B S T R A C T}

\begin{tabular}{|l|}
\hline K e y w o r d s \\
Tropical seaweeds, \\
bioformulations, LBS6, \\
LBD1, Tricyclazole and \\
Carbendazim
\end{tabular}

\section{Introduction}

Rice (Oryza sativa L.) is an important cereal crop and staple food for large population of the world especially in South and Southeast Asia. The global annual demand for rice will be around 800 million tons by 2025 in view of expected increase in population.

More than 90 per cent of the world's rice is grown and consumed in Asia. In this region it represents a high-value commodity crop. The global production of rice has been estimated 697.22 million tons at an average yield of 4.4 tons $\mathrm{ha}^{-1}$ is being harvested from 158.43 million ha annually producing 21 per cent of worlds food calorie supply (FAO, 2012).

10 October 2018

\begin{abstract}
A field experiment was conducted during Kharif 2017-2018 to study the effect of tropical red seaweed (Kappaphycus alvarezii) bioformulations (LBS 6 and LBD 1 in relieving the fungicidal stress and imparting the resistance to blast disease) in rice. Foliar application of LBS6 @ $1 \mathrm{ml} / 1$ was found to be statistically superior in improving yield parameters viz., in $(6.94 \mathrm{~kg} / \mathrm{plot})$ and grain weight $(5.59 \mathrm{~kg} / \mathrm{plot})$. There was 41.90 and $27.04 \mathrm{per}$ cent increase over control with respect to straw and grain yield in $\mathrm{T}_{3}$ (LBS6 @ $1.0 \mathrm{ml} / \mathrm{l}$ ). Lower disease severity of 11.52 per cent was recorded in $\mathrm{T}_{1}$ (tricyclazole $75 \% \mathrm{WP}$ ). The bioformulation LBD1 $\left(\mathrm{T}_{4}\right)$ treated plots recorded 12.11 per cent disease severity. However there was no significant difference between $\mathrm{T}_{1}$
par with the fungicide in controlling the disease.
\end{abstract}


Biotic and abiotic stresses are the primary constraints in rice production worldwide. These stresses are responsible for large-scale crop loss each year and with the predicted climate change, such losses are expected to increase. Therefore, research for sustainable approaches to alleviate these stresses is a high priority (Bird et al., 2016). Among biotic stresses, rice blast caused by Magnaporthe oryzae is of significant economic importance and serious threat with yield losses up to 60100 per cent (Yashaswini et al., 2017).

Since fungal diseases are most devastating in rice worldwide, fungicides are important tools to manage these diseases. Consequences of heavy usage of pesticides specifically fungicides leads to fungicidal stress. Apart from fungicidal stress, application of fungicides contributes more towards the residual level. Recently, there was ban on India's basmati rice exports as Iran imposed caps on imports because of high MRL of 0.01 ppm (Maximum Residual Level). Reducing the pesticides in agriculture is essential to minimize the environmental impact and improve the sustainability of agricultural systems (Van Oosten et al., 2017).

Hence agricultural growing practices have been evolving towards organic, sustainable or environmental friendly systems. Red seaweed extracts contain a wide range of bioactive compounds that are mostly still unknown.

Seaweed extracts are the biostimulants which can be applied as foliar spray for enhancing the plant growth, tolerance to abiotic stress, photosynthetic activity and also provide resistance to many diseases as they serves as a source of large number of compounds such as laminarin, fucans, ulvans and carrageenans, which act as elicitor molecules against pathogens (Shukla et al., 2016). Many of these extracts are also able to counteract the effect of biotic and abiotic stresses, enhancing quality and crop yield by stimulating plant physiological processes (Ziosi et al., 2013). The research of red seaweed extracts and their formulated products on rice is very limited in India and mainly done in the plain land rice ecosystems (Devi and Mani, 2015). However, the effects of $K$. alvarezii on rice with respect to fungicidal stress and induced disease resistance have not been studied. Therefore, the current investigations were carried out to know the biological effects of bioformulations (LBD1 as defence activator and LBS6 growth stimulant) obtained from tropical red seaweed (Kappaphycus alvarezii) in relieving the fungicidal stress and imparting the blast disease resistance in rice

\section{Materials and Methods}

\section{Seaweed extracts}

Bioformulations of red tropical seaweed (Kappaphycus alvarezii) were procured from Sea6 energy lab, NCBS, Bengaluru

\section{Experimental design}

In order to determine the possible effect of seaweed bioformulations in relieving the fungicidal stress, field experiment was conducted during the Kharif 2017-18 at ZARS, V.C Farm, Mandya. Rice variety IR-64 was used in the experiment which is susceptible to blast disease. The net plot size of $5 \mathrm{~m}^{2}$ was maintained for each replication with $20 \mathrm{~cm}$ distance between rows and $15 \mathrm{~cm}$ between plants. Total of 13 treatments were selected and laid out as per Random Complete Block Design (RCBD).

\section{Stress induction}

Fungicidal stress was induced by spraying of selected fungicides at the interval of 15 days to rice in field condition. First spray was taken at 15 days after transplanting. Total four 
sprays were taken up in study. Treatment details and dosages are furnished below. Observations viz., disease severity and yield parameters viz., number of panicles, panicle weight and panicle length were taken in to consideration.

\section{Disease severity}

After the second spray, plots were inspected periodically until harvest to determine the severity of blast disease. Five random plants per plot were selected to assess the severity of the disease. Assessment of blast was carried out by 0-9 scale (Standard Evaluation System, 1996).

\section{Growth and yield parameters}

In each trial plot, with an area of $1 \mathrm{~m}^{2}$ was randomly selected. Meter square and whole plots were harvested individually and the grain as well as straw yields were determined using electronic balance. Sub-samples of randomly selected five plants were taken from every plot to determine the number of panicles, panicle length and weight, straw and grain weight. Analysis and interpretation of the experimental data was performed as per RCBD.

\section{Experimental details}

$\mathrm{T}_{1}$ : Tricyclazole $75 \% \mathrm{WP} @ 0.6 \mathrm{~g} / \mathrm{l}$

$\mathrm{T}_{2}$ : Carbendazim 50\%WP @ $1.0 \mathrm{~g} / \mathrm{l}$

T3:LBS6 @ $1.0 \mathrm{ml} / \mathrm{l}$

$\mathrm{T}_{4}: \mathrm{LBD} 1 @ 2.0 \mathrm{ml} / 1$

$\mathrm{T}_{5}$ : Tricyclazole $75 \% \mathrm{WP}+\mathrm{LBS6} @ 0.6 \mathrm{~g}+$ $1.0 \mathrm{ml} / 1$

T6: Tricyclazole $75 \% \mathrm{WP}+$ LBS6 @ 0.4g + $1.0 \mathrm{ml} / \mathrm{l}$
$\mathrm{T}_{7}$ : Tricyclazole $75 \% \mathrm{WP}+\mathrm{LBD} 1 @ 0.4 \mathrm{~g}+1$ $\mathrm{ml} / \mathrm{l}$

$\mathrm{T}_{8}$ : Tricyclazole $75 \% \mathrm{WP}+\mathrm{LBD} 1 @ 0.4 \mathrm{~g}+$ $2 \mathrm{ml} / \mathrm{l}$

T9: Carbendazim $50 \% \mathrm{WP}+\mathrm{LBS6} @ 1.0 \mathrm{~g}+$ $1 \mathrm{ml} / 1$

$\mathrm{T}_{10}$ : Carbendazim $50 \% \mathrm{WP}+$ LBS6 @ 0.6g + $1.0 \mathrm{ml} / 1$

$\mathrm{T}_{11}$ : Carbendazim $50 \% \mathrm{WP}+\mathrm{LBD} 1 @ 0.6 \mathrm{~g}+$ $1 \mathrm{ml} / \mathrm{l}$

$\mathrm{T}_{12}$ : Carbendazim $50 \% \mathrm{WP}+\mathrm{LBD} 1 @ 0.6 \mathrm{~g}+$ $2 \mathrm{ml} / \mathrm{l}$

$\mathrm{T}_{13}$ : Untreated check (water spray)

\section{Results and Discussion}

Efficacy of seaweed bioformulations in management of rice blast in field condition

The effect of seaweed extracts with fungicides and their combinations as explained in the material and methods was investigated during Kharif 2017-18 in field condition. Lower disease severity of 11.52 per cent was recorded in $\mathrm{T}_{1}$ (tricyclazole $75 \% \mathrm{WP}$ ). The bioformulation LBD1 $\left(\mathrm{T}_{4}\right)$ treated plots recorded 12.11 per cent disease severity (Table 1). However there was no significant difference between $T_{1}$ and $T_{4}$. It was observed that LBD1 was on par with the fungicide in controlling the disease. Severity of the disease was 19.56 per cent in carbendazim $50 \% \mathrm{WP}$ @ $1 \mathrm{~g} / \mathrm{l}$ treated plots.

Whereas the combination of carbendazim 50 \%WP @ 0.6g/l and LBD1@ @ml/ $1\left(\mathrm{~T}_{12}\right)$ showed lower disease severity (13.80\%) compared to carbendazim alone. The seaweed bioformulation LBS6 recorded disease severity of 20.50 per cent. However, there was 
no significant difference in disease severity between combinations of LBS6 with both fungicides. LBD1 recorded 33.15 per cent disease decrease over control, whereas tricyclazole $75 \%$ WP was efficient in decreasing the disease up to 44.38 per cent. Disease severity was found to be statistically superior in seaweed bioformulation LBD1@ $2 \mathrm{ml} / \mathrm{l}$ treated plot which was on par with the fungicide tricyclazole. When carbendazim was combined with LBD-1, disease severity was reduced, which directly implies that LBD-1 had increased the efficacy of the fungicide and there by reduced the disease.

Oligosaccharides and carrageenans present in the seaweed bioformulations are known induce plant defence responses by modulating the activity of different defence pathways, including salicylate, jasmonate and ethylene signalling pathways. Foliar application with 0.5 per cent seaweed extract reduced diseases caused by Alternaria solani and Xanthomonas campestris pv. vesicatoria by up to 63.00 per cent and 44.00 per cent respectively in tomato (Ali et al., 2016). Presence of iota (1), lambda $(\lambda)$ and kappa $(\kappa)$ carrageenan in seaweeds decreased the replication and symptom expression of Tomato Chlorotic Dwarf Viroid (TCDVd) in tomato. There was up regulation of defense related genes viz., allene oxide synthase (AOS), lipoxygenase (LOX) and PR1, suggesting that $\lambda$-carrageenan induced defense against TCDVd in tomato (Sangha et al., 2015). Similar compounds might be present in LBD-1 which has suppreseed the disease by inducing defence response

\section{Yield parameters}

Foliar application of seaweed bioformulations was efficacious in improving the yield. The yield parameter results of randomly selected five plants revealed that LBS6 and the combination of carbendazim $50 \% \mathrm{WP}+$ LBS6 were effective. Number of panicles recorded higher in $\mathrm{T}_{10}$ (average of 23.90/ plant). LBS 6 treated plants recorded 23.50 panicles/plant (Table 2).

Length of panicles was more in plants treated with LBS6 @ $1 \mathrm{ml} / 1(16.19 \mathrm{~cm})$ followed by $\mathrm{T}_{6}$ (tricyclazole 75 \%WP @ $0.4 \mathrm{~g} \mathrm{~L}^{-1}+$ LBS6 @ $1 \mathrm{ml} / \mathrm{l})$. Panicle weight was higher in LBS 6 @ $1 \mathrm{ml} / 1$ treated plants with $31.60 \mathrm{~g}$ which was followed by $\mathrm{T}_{7}$ (carbendazim $50 \% \mathrm{WP}+$ LBS6). Untreated check recorded reduced panicle length as well as weight $(15.15 \mathrm{~cm}$ and $22.80 \mathrm{~g}$ respectively). Significant differences with respect to the grain and straw yield was observed in treated plants when compared to untreated control in randomly selected five plants. Highest straw weight of $22.90 \mathrm{~g} /$ plant was recorded in $\mathrm{T}_{10}$ (carbendazim 50\%WP @ $0.6 \mathrm{~g} / 1$ + LBS6 @ $1 \mathrm{ml} / \mathrm{l})$. Results of randomly selected five plants revealed that there were statistically remarkable differences with respect to the grain and straw yield in treated plants when compared to untreated control. Highest straw weight and grain weight of $32.12 \mathrm{~g}$ and $27.27 \mathrm{~g} /$ plant respectively was recorded in $\mathrm{T}_{3}$ (LBS6 @ $1.0 \mathrm{ml} / \mathrm{l}$ ). Tricyclazole $75 \% \mathrm{WP} @ 0.6 \mathrm{~g} / \mathrm{l}$ and carbendazim 50 \%WP @ 1.0 g/l alone recorded $27.42 \mathrm{~g}$ (straw weight), $24.24 \mathrm{~g}$ (grain weight) and $25.76 \mathrm{~g}$ (straw weight), $26.21 \mathrm{~g}$ (grain weight) respectively (Table 3 ).

Whereas combination of fungicides and seaweed bioformulations i.e., $\mathrm{T}_{5}$ (tricyclazole $75 \% W P @ 0.6 \mathrm{~g} / 1+\mathrm{LBS6} @ 1 \mathrm{ml} / \mathrm{l}), \mathrm{T}_{6}$ (tricyclazole $75 \% W P @ 0.4$ g/l + LBS6 @ 1 $\mathrm{ml} / \mathrm{l}$ ), $\mathrm{T}_{7}$ (tricyclazole $75 \% \mathrm{WP} @ 0.4 \mathrm{~g} / \mathrm{l}+$ LBD1@1 ml/l), T8 (tricyclazole 75\%WP @ $0.4 \mathrm{~g} / \mathrm{l}+\mathrm{LBD} 1 @ 2 \mathrm{ml} / \mathrm{l}$ ), $\mathrm{T}_{9}$ (carbendazim 50 $\% \mathrm{WP}+$ LBS6 @ 1.0g/l + 1ml/l), $\mathrm{T}_{10}$ (carbendazim 50 \%WP + LBS6 @ 0.6g/1 + 1.0 $\mathrm{ml} / \mathrm{l}$ ), $\mathrm{T}_{11}$ (carbendazim $50 \% \mathrm{WP}+\mathrm{LBD} 1 @$ $0.6 \mathrm{~g} / \mathrm{l}+1 \mathrm{ml} / \mathrm{l}$ ) and $\mathrm{T}_{12}$ (carbendazim 50 $\% \mathrm{WP}+\mathrm{LBD} 1 @ 0.6 \mathrm{~g} / \mathrm{l}+2 \mathrm{ml} / \mathrm{l})$ recorded higher straw and grain weight compared to fungicide alone (Table 3). 
Table.1 Effect of seaweed bioformulations on the severity of rice neck blast disease during Kharif 2017-18

\begin{tabular}{c|l|c|c|}
$\begin{array}{c}\text { Treatm } \\
\text { ents }\end{array}$ & \multicolumn{1}{|c|}{ Treatment details } & Per cent disease & $\begin{array}{c}\text { Ker cent decrease } \\
\text { over control }\end{array}$ \\
\hline $\mathrm{T}_{1}$ & Tricyclazole @ $0.6 \mathrm{~g} / \mathrm{l}$ & $11.52(19.83) *$ & 47.08 \\
\hline $\mathrm{T}_{2}$ & Carbendazim @ 1 g/l & $19.56(26.24)$ & 10.15 \\
\hline $\mathrm{T}_{3}$ & LBS6@ 1ml/1 & $20.50(26.91)$ & 5.80 \\
\hline $\mathrm{T}_{4}$ & LBD1@ 0 ml/1 & $12.11(20.35)$ & 44.38 \\
\hline $\mathrm{T}_{5}$ & Tricyclazole+LBS6 $(0.6 \mathrm{~g}+1 \mathrm{ml} / \mathrm{l})$ & $13.29(21.37)$ & 38.92 \\
\hline $\mathrm{T}_{6}$ & Tricyclazole+LBS6 $(0.4 \mathrm{~g}+1 \mathrm{ml} / \mathrm{l})$ & $12.11(20.35)$ & 44.36 \\
\hline $\mathrm{T}_{7}$ & Tricyclazole+LBD1 $(0.4 \mathrm{~g}+1 \mathrm{ml} / \mathrm{l})$ & $13.44(21.49)$ & 38.27 \\
\hline $\mathrm{T}_{8}$ & Tricyclazole+LBD1 $(0.4 \mathrm{~g}+2 \mathrm{ml} / \mathrm{l})$ & $12.97(21.10)$ & 40.43 \\
\hline $\mathrm{T}_{9}$ & Carbendazim+LBS6 $(1 \mathrm{~g}+1 \mathrm{ml} / \mathrm{l})$ & $18.74(25.63)$ & 13.92 \\
\hline $\mathrm{T}_{10}$ & Carbendazim+LBS6 $(0.6 \mathrm{~g}+1 \mathrm{ml} / \mathrm{l})$ & $18.15(25.20)$ & 16.62 \\
\hline $\mathrm{T}_{11}$ & Carbendazim+LBD1 $(0.6 \mathrm{~g}+1 \mathrm{ml} / \mathrm{l})$ & $18.38(25.38)$ & 15.54 \\
\hline $\mathrm{T}_{12}$ & Carbendazim+LBD1 $(0.6 \mathrm{~g}+2 \mathrm{ml} / \mathrm{l})$ & $13.80(21.80)$ & 36.60 \\
\hline $\mathrm{T}_{13}$ & Untreated check & $21.77(27.80)$ & \\
\hline & SEm \pm & $\mathbf{0 . 3 3 2}$ & \\
\hline & C.D at 5\% & $\mathbf{1 . 0 1 6}$ & \\
\hline & CV \% & $\mathbf{2 . 0 2 1}$ & \\
\hline
\end{tabular}

*Figures in parenthesis are arcsine transformed values

Table.2 Effect of seaweed bioformulations on panicles parameters during Kharif- 2017-18

\begin{tabular}{|c|c|c|c|c|}
\hline \multirow[t]{2}{*}{ Treatments } & \multirow[t]{2}{*}{ Treatment details } & \multicolumn{3}{|c|}{ Kharif- 2017-18 } \\
\hline & & $\begin{array}{c}\text { No. of } \\
\text { panicles }\end{array}$ & $\begin{array}{c}\text { Panicle } \\
\text { length }(\mathrm{cm})\end{array}$ & $\begin{array}{c}\text { Panicle } \\
\text { weight (g) }\end{array}$ \\
\hline $\mathbf{T}_{1}$ & Tricyclazole@0.6g/1 & 19.20 & 15.70 & 24.60 \\
\hline $\mathrm{T}_{2}$ & Carbendazim@1g/l & 22.05 & 15.90 & 27.30 \\
\hline $\mathbf{T}_{3}$ & LBS6@1ml/1 & 25.25 & 16.19 & 31.60 \\
\hline $\mathbf{T}_{4}$ & LBD1@ 2 ml/l & 20.80 & 15.75 & 28.90 \\
\hline $\mathbf{T}_{5}$ & Tricyclazole+LBS6 $(0.6 \mathrm{~g}+1 \mathrm{ml} / \mathrm{l})$ & 23.15 & 15.89 & 29.10 \\
\hline$T_{6}$ & Tricyclazole+LBS6 $(0.4 \mathrm{~g}+1 \mathrm{ml} / \mathrm{l})$ & 23.60 & 15.91 & 29.70 \\
\hline $\mathbf{T}_{7}$ & Tricyclazole+LBD1 $(0.4 \mathrm{~g}+1 \mathrm{ml} / \mathrm{l})$ & 21.45 & 15.32 & 28.70 \\
\hline $\mathbf{T}_{8}$ & Tricyclazole+LBD1 $(0.4 \mathrm{~g}+2 \mathrm{ml} / \mathrm{l})$ & 21.00 & 15.19 & 27.90 \\
\hline$T_{9}$ & Carbendazim+LBS6 $(1 \mathrm{~g}+1 \mathrm{ml} / \mathrm{l})$ & 21.05 & 15.75 & 30.60 \\
\hline $\mathbf{T}_{10}$ & Carbendazim+LBS6 $(0.6 \mathrm{~g}+1 \mathrm{ml} / \mathrm{l})$ & 23.90 & 15.70 & 29.60 \\
\hline $\mathbf{T}_{11}$ & Carbendazim+LBD1 $(0.6 \mathrm{~g}+1 \mathrm{ml} / \mathrm{l})$ & 21.05 & 15.21 & 25.60 \\
\hline $\mathbf{T}_{12}$ & Carbendazim+LBD1 $(0.6 \mathrm{~g}+2 \mathrm{ml} / \mathrm{l})$ & 22.45 & 15.45 & 24.90 \\
\hline \multirow[t]{4}{*}{$\mathrm{T}_{13}$} & Untreated check & 16.00 & 15.15 & 22.80 \\
\hline & SEm \pm & 1.69 & 0.22 & 0.21 \\
\hline & C.D at $5 \%$ & 5.18 & 0.69 & 0.66 \\
\hline & $\mathrm{CV} \%$ & 11.00 & 1.89 & 1.08 \\
\hline
\end{tabular}


Table.3 Effect of seaweed bioformulations on yield parameters of rice during Kharif- 2017-18

\begin{tabular}{|c|c|c|c|c|c|c|c|c|c|}
\hline \multirow{2}{*}{$\begin{array}{l}\text { Treat } \\
\text { ments }\end{array}$} & \multirow[t]{2}{*}{ Treatment details } & \multicolumn{2}{|c|}{ A verage of 5 plants (g) } & \multicolumn{2}{|c|}{$\begin{array}{l}\text { Meter square area } \\
(\mathbf{k g})\end{array}$} & \multicolumn{2}{|c|}{ whole plot (kg) } & \multicolumn{2}{|c|}{$\begin{array}{l}\% \text { increase over } \\
\text { control }\end{array}$} \\
\hline & & $\begin{array}{c}\text { Straw } \\
\text { weight }\end{array}$ & $\begin{array}{l}\text { Grain } \\
\text { weight }\end{array}$ & $\begin{array}{c}\text { Straw } \\
\text { weight }\end{array}$ & $\begin{array}{c}\text { Grain } \\
\text { weight }\end{array}$ & $\begin{array}{c}\text { Straw } \\
\text { weight }\end{array}$ & $\begin{array}{c}\text { Grain } \\
\text { weight }\end{array}$ & $\begin{array}{l}\text { Straw } \\
\text { weight }\end{array}$ & $\begin{array}{c}\text { Grain } \\
\text { weight }\end{array}$ \\
\hline $\mathbf{T}_{1}$ & Tricyclazole@0.6g/l & 27.42 & 24.24 & 1.57 & 1.46 & 5.66 & 4.80 & 28.80 & 14.93 \\
\hline$\overline{T_{2}}$ & Carbendazim@1g/l & 25.76 & 26.21 & 1.51 & 1.53 & 5.21 & 5.31 & 22.62 & 23.09 \\
\hline$\overline{T_{3}}$ & LBS6@1ml/1 & 32.12 & 27.27 & 1.72 & 1.56 & 6.94 & 5.59 & 41.90 & 27.04 \\
\hline$\overline{T_{4}}$ & LBD1@ 2 ml/l & 24.70 & 25.30 & 1.48 & 1.50 & 4.92 & 5.06 & 18.08 & 19.35 \\
\hline$\overline{T_{5}}$ & Tricyclazole+LBS6 $(0.6 \mathrm{~g}+1 \mathrm{ml} / \mathrm{l})$ & 28.03 & 25.76 & 1.59 & 1.51 & 5.83 & 4.68 & 30.82 & 12.78 \\
\hline $\mathrm{T}_{6}$ & Tricyclazole+LBS6 $(0.4 \mathrm{~g}+1 \mathrm{ml} / \mathrm{l})$ & 29.85 & 26.67 & 1.65 & 1.54 & 6.32 & 5.43 & 36.22 & 24.83 \\
\hline$\overline{T_{7}}$ & Tricyclazole+LBD1 $(0.4 \mathrm{~g}+1 \mathrm{ml} / \mathrm{l})$ & 28.03 & 26.67 & 1.59 & 1.54 & 5.83 & 5.43 & 30.82 & 24.83 \\
\hline$\overline{T_{8}}$ & Tricyclazole+LBD1 $(0.4 \mathrm{~g}+2 \mathrm{ml} / \mathrm{l})$ & 28.33 & 26.06 & 1.60 & 1.52 & 5.91 & 5.26 & 31.78 & 22.49 \\
\hline$\overline{T_{9}}$ & Carbendazim+LBS6 (1g+1ml/l) & 31.09 & 26.21 & 1.69 & 1.53 & 6.66 & 5.31 & 39.46 & 23.09 \\
\hline $\mathbf{T}_{10}$ & Carbendazim+LBS6 $(0.6 \mathrm{~g}+1 \mathrm{ml} / \mathrm{l})$ & 30.91 & 26.82 & 1.68 & 1.55 & 6.61 & 5.47 & 39.00 & 25.40 \\
\hline$\overline{T_{11}}$ & Carbendazim+LBD1 $(0.6 \mathrm{~g}+1 \mathrm{ml} / \mathrm{l})$ & 26.52 & 25.45 & 1.54 & 1.50 & 5.41 & 5.10 & 25.56 & 20.00 \\
\hline $\mathbf{T}_{12}$ & Carbendazim+LBD1 $(0.6 \mathrm{~g}+2 \mathrm{ml} / \mathrm{l})$ & 24.85 & 26.21 & 1.48 & 1.53 & 4.96 & 5.31 & 18.76 & 23.09 \\
\hline \multirow[t]{4}{*}{$\mathrm{T}_{13}$} & Untreated check & 21.52 & 21.36 & 1.37 & 1.37 & 4.06 & 3.99 & & \\
\hline & SEm \pm & 1.617 & 1.534 & 0.053 & 0.050 & 0.780 & 0.450 & & \\
\hline & C.D at $5 \%$ & 4.940 & 4.689 & 0.163 & 0.154 & 2.384 & 1.375 & & \\
\hline & CV \% & 4.801 & 4.739 & 13.197 & 14.005 & 5.007 & 15.206 & & \\
\hline
\end{tabular}


$\mathrm{T}_{9}$ (carbendazim $50 \% \mathrm{WP}+$ LBS6 @ 1.0g/l + $1 \mathrm{ml} / \mathrm{l}$ ) and $\mathrm{T}_{10}$ (carbendazim $50 \% \mathrm{WP}+$ LBS6 @ $0.6 \mathrm{~g} / \mathrm{l}+1.0 \mathrm{ml} / \mathrm{l})$ were found to be superior to $\mathrm{T}_{2}$ (carbendazim 50\%WP @ $1.0 \mathrm{~g} / \mathrm{l}$ ).

Data of each plot $\left(\mathrm{m}^{2}\right.$ area) revealed that the straw weight was recorded higher in LBS 6 @ $1 \mathrm{ml} / \mathrm{l}$ treated plots $(1.72 \mathrm{~kg})$ which was followed by $\mathrm{T}_{9}$ (carbendazim $50 \% \mathrm{WP}+$ LBS6 @ 1.0g/l + 1ml/l) and $\mathrm{T}_{10}$ (carbendazim $50 \% \mathrm{WP}+$ LBS6@0.6g/l + $1.0 \mathrm{ml} / \mathrm{l})$ with straw weight of 1.69 and $1.68 \mathrm{~kg}$ respectively. However, $\mathrm{T}_{3}$ was found to be statistically superior over $T_{9}$ and $T_{10}$, however there was no significant difference between $\mathrm{T}_{9}$ (carbendazim 50\%WP + LBS6 @ 1.0g/l + $1 \mathrm{ml} / \mathrm{l}$ ) and $\mathrm{T}_{10}$ (carbendazim $50 \% \mathrm{WP}+$ LBS6 @ $0.6 \mathrm{~g} / \mathrm{l}+1.0 \mathrm{ml} / \mathrm{l}$ ) was observed. Highest grain weight of $1.56 \mathrm{~kg}$ was recorded in $\mathrm{T}_{3}$ (LBS $6 @ 1 \mathrm{ml} / \mathrm{l}$ ) treated $\mathrm{m}^{2}$ plots followed by $\mathrm{T}_{6}$ (tricyclazole $75 \% \mathrm{WP}+$ LBS6 @ 0.4g/l + $1.0 \mathrm{ml} / \mathrm{l})$ with grain weight of $1.54 \mathrm{~kg}$. Combination of tricyclazole $75 \% \mathrm{WP}$ and LBS 6 yielded more than tricyclazole 75 $\% W P$ alone with respect to both straw and grain weight. However yield was found to be lower in untreated check (Table 3).

There was significant difference between the treatments and the control with respect to whole plot yield (straw and grain). Carbendazim 50 \%WP (@ 1.0 g/l) alone recorded $5.21 \mathrm{~kg}, 5.31 \mathrm{~kg}$ of straw and grain yield respectively (Table 3 ).

Straw and grain yield in tricyclazole $75 \% \mathrm{WP}$ (@ $0.6 \mathrm{~g} / \mathrm{l}$ treated plot was 5.66 and $4.80 \mathrm{~kg}$ respectively. However, increasing trend was observed in yield when these two fungicides combined with seaweed bioformulation (LBS-6). Straw and grain yield were recorded higher in $\mathrm{T}_{3}$ (LBS6 @ $1.0 \mathrm{ml} / \mathrm{l}$ ) with $6.94 \mathrm{~kg}$ and $5.59 \mathrm{~kg}$ respectively. While in control, yield was significantly lower (4.06 and 3.99 $\mathrm{kg}$ straw and grain weight respectively). There was 41.90 and 27.04 per cent increase over control with respect to straw and grain yield was recorded in $\mathrm{T}_{3}$ (LBS6 @ $1.0 \mathrm{ml} / \mathrm{l}$ ).

The present study indicates that the seaweed bioformulations especially LBS 6 had improved the efficacy of the fungicides which was evident from the increased level of yields. Upturn of all the parameters has directly reflected on yield. Increased yields are also attributed to stimulation of mineral nutrient uptake with increased accumulation of macro and micro nutrients. Zodape et al., (2011) reported that there was elevated accumulation of both macronutrients $(\mathrm{N}, \mathrm{P}, \mathrm{K}$, $\mathrm{Ca}$ and $\mathrm{S})$ and micronutrients $(\mathrm{Mg}, \mathrm{Zn}, \mathrm{Mn}$ and $\mathrm{Fe}$ ) and a subsequent increase in yield of tomato fruits $(60.89 \%)$ compared to control plants when tomato plants were sprayed with seaweed extracts (Kappaphycus alvarezii).

Similar results were obtained by Kavitha et al., (2008) who reported that spraying of seaweed extract @ 0.3 per cent on rice twice at 50 per cent flowering and at milk stages recorded significantly higher growth and yield attributes and was followed by spraying of seaweed extract@0.3 per cent at milk stage. Spraying of seaweed extract @ 0.3 per cent at fifty per cent flowering and milk stages recorded 26 per cent higher grain yield (6055 $\mathrm{kg} \mathrm{ha}^{-1}$ ) when compared to control (4432 kg $\left.\mathrm{ha}^{-1}\right)$.

\section{References}

Ali, N., Antonio, R., Adesh, R. and Jayaraman, J., 2016. Ascophyllum extract application causes reduction of disease levels in field tomatoes grown in a tropical environment. Crop Protect, 83: 67-75

Anonymous, 2016. Annual report (2016-17), Department of agriculture, cooperation and farmers' welfare, New Delhi, p. 3

Bird, J., ROY, S., Shah, T., Aggarwal, P., Smakhtin, V., Amarnath, G., 
Amarasinghe, U. A., Pavelic, P. and Mccornick, P. G., 2016. Adapting to climate variability and change in India. In: Biswas, A. K. and Tortajada, C., (eds) Water security. Climate change and sustainable development. Springer, Singapore, pp 41-63.

Devi, N. L. and Mani, S., 2015. Effect of seaweed saps Kappaphycus alvarezii and Gracilaria on growth, yield and quality of rice. Indian J. Sci. Techn., 8: $19: 22$.

FAO-Food and Agriculture Organization. 2012. FAOSTAT Database FAO, Rome, www.faostat.fao.org

Kavitha, M. P., Ganesaraja, V. and Paulpandi, V. K., 2008. Effect of foliar spraying of sea weed extract on growth and yield of rice (Oryza sativa L.). Agric. Sci. Digest, 28: 127 - 129.

Sangha, J. S., Saveetha, K., Wajahatullah, K., Navratan, S. B., Rudra, P. S., Alan, T. C. and Balakrishnan, P., 2015. $\lambda$ Carrageenan suppresses tomato chlorotic dwarf viroid (TCDVd) replication and symptom expression in tomatoes. Mar. Drugs, 13: 2875-2889.

Shukla, P. S., Tudor, B., Alan, T. C. and Balakrishnan, P., 2016. Carrageenans from red seaweeds as promoters of growth and elicitors of defense response in plants. Front. Mar. Sci., 3: 81.

Van Oosten, M. J., Pepe, O., De Pascale, S., Silletti, S. and Maggio, A., 2017. The role of biostimulants and bioeffectors as alleviators of abiotic stress in crop plants. Chem. Biol. Techn. Agric., 4: 15.

Yashaswini, C. H., Narayan, R. P., Pushpavati, B., Srinivasa, R. and Seshu, M. M., 2017. Prevalence of rice blast (Magnaporthe oryzae) incidence in south India. Bull. Env. Pharmacol. Life Sci., 6: 370-373

Ziosi, V., Zandoli, R. and Di Nardo, A., 2013. Biological activity of different botanical extracts as evaluated by means of an array of in vitro and in vivo bioassays. Acta. Hortic, 1009: 61-66.

Zodape, S. T., Abha, G., Bhandari, S. C., Rawat, U. S., Chaudhary, D. R., Eswaran, K. and Chikara, J., 2011. Foliar application of seaweed sap as biostimulant for enhancement of yield and quality of tomato (Lycopersicon esculentum Mill.). J. Sci. Indust., 70: 215-219.

\section{How to cite this article:}

Sahana, N. Banakar, K.T. Rangaswami and Prasanna Kumar, M.K. 2018. Unravelling the Effect of Seaweed Bio Formulations in Relieving Biotic and Abiotic Stress in Rice. Int.J.Curr.Microbiol.App.Sci. 7(10): 543-550. doi: https://doi.org/10.20546/ijcmas.2018.710.060 